\title{
Analysis of Mathematic Representation Ability of Informatics Engineering Students in Assignment Problems
}

\author{
Niska Shofia ${ }^{1}$, Siti Rochana ${ }^{2}$, Suryo Widodo ${ }^{3}$ \\ ${ }^{1,2}$ Informatics Engineering, Engineering, Universitas Nusantara PGRI Kediri \\ ${ }^{3}$ Mathematics Education, Teacher and Education Science \\ University of Nusantara PGRI Kediri \\ E-mail : niskashofia@unpkediri.ac.id
}

\begin{abstract}
Mathematics is a field of science that can improve a person's ability to think logically, critically, rationalistically, effectively, carefully and efficiently. To find out a person's ability to think logically, critically, rationalistically, effectively, carefully and efficiently in solving mathematical problems, an analysis of mathematical representations is needed. Mathematical representation is needed in solving Operations Research problems, because operations research uses a mathematical model as a problem-solving approach. This research discusses the mathematical representation ability of informatics engineering students in solving assignment problems in Operations Research courses. The research method used includes descriptive research with a qualitative research approach. Data were taken directly from the research location using interviews and tests on 3 research subjects, namely students with high, medium and low abilities. The subject selection is based on the results of the dialogue between the researcher and the student's mathematics subject lecturer. Based on the results of research, high-ability students can complete multiple representations both visually, symbolically and verbally. Likewise for the mathematical representation of moderate-capable students is having multiple representations, but there are steps in solving that are missed in verbal representations. Low-ability students only provide visual and verbal representations, while symbolic representations still have errors. However, all three are still lacking in terms of the implementation of the final results.
\end{abstract}

Keywords: mathematical representation, multiple representations, assignment problems, operations research

\section{INTRODUCTION}

Mathematics is one of the disciplines that has a unique characteristic, which is full of concepts, ranging from simple concepts to complex and abstract concepts. Mathematics requires conceptual understanding, if a concept is not understood, then the next concept based on the previous concept will be difficult or even impossible to understand (Shofia, 2019). NCTM (2000) states that representation is the way someone uses to communicate their mathematical answers or ideas. Furthermore, the representation raised by students is an expression of mathematical ideas or ideas displayed by students in an effort to find a solution to the problem they are facing. The forms of interpretation given can be in the form of words or verbs, writing, pictures, tables, graphics, concrete objects, mathematical symbols and others. (Sabirin, 2014).

Mathematical representation is indispensable in understanding concepts and solving mathematical problems, which can improve students' mathematical 
communication skills and play a role in increasing mathematical competence. The level of student mathematics representation is actually also influenced by the level of student reasoning. Meanwhile, the level of student reasoning is influenced by the level of student intelligence (Shofia, 2019). So, it can be interpreted that the level of student intelligence also affects the level of student mathematical representation. In general, the level of student intelligence is divided into three, namely students with high, medium, and low abilities. Highly capable students usually have high reasoning because they have a mature analogy to present a problem so that it can be solved.(Irawati, Sri, 2016).

Research conducted by Ulandari (2015) Finds Students who have the basic ability level of the upper group, their visual representation ability is in the high category, their symbol representation ability is in the medium category, their verbal representation ability is in the low category. Students who have the intermediate level of basic ability, the ability of visual representation and symbols are in the medium category and their verbal representation skills are in the very low category. Students who have the basic level of the lower group, their visual representation ability is in the medium category, their symbol representation ability is in the low category, their verbal representation ability is in the very low category. To find out the ability of informatics engineering students in thinking logically, critically, rationalist, effective, careful and efficient in solving mathematical problems, an analysis of mathematical representations is needed. Mathematical representation is also needed in solving Operations Research problems, because operations research uses a mathematical model as a problem-solving approach, besides that, based on the researcher's discussion with the lecturers who teach the subject, the level of student mastery is still lacking, seen from the quiz scores obtained on average. The average is 70 , so with this analysis it is hoped that the ability of students to have mathematical representations can be used to develop teaching methods for lecturers. This study discusses the mathematical representation ability of informatics engineering students at Nusantara University PGRI Kediri in solving assignment problems in Operations Research courses based on mathematical abilities.

\section{RESEARCH METHOD}

The research method used by the author is a qualitative research method, because the data collection is done in a narrative and visual way that is collected directly from the research location. The research subjects were 3 students of the Informatics Engineering Study Program, Universitas Nusantara PGRI Kediri who have high, medium and low abilities. The selection of research subjects was based on the dialogue between the researcher and the teaching lecturer on the mathematics subject that taught the students and was based on the value of the mathematics subject obtained. This method uses test and interview instruments. The steps in data collection included: (1) preparing questions; (2) distributing questions to students; (3) Supervising students in solving questions; (4) checking student work results; (5) evaluate; (6) analyze the test results.

The data analysis technique used in this qualitative research was analyzed using the flow as proposed by Mills and Huberman (in Sugiyono, 2007) are: (1) data reduction, (2) data presentation, (3) drawing conclusions. Meanwhile, indicators of the ability of mathematical representations studied were visual representations, symbolic representations and verbal representations. 
Table 1. Indicator of Students' Mathematical Representation Ability

\begin{tabular}{lll}
\hline No & Aspects of Representation & \multicolumn{1}{c}{ Representation Ability Indicator } \\
\hline 1 & Visual Representation & Students restate data or information from a representation \\
& Table & $\begin{array}{l}\text { to a table representation } \\
\text { Students create charts to clarify problems and facilitate } \\
\text { resolution }\end{array}$ \\
& Chart & $\begin{array}{l}\text { Students operate a symbol and check how it is solved } \\
\text { Students answer questions by explaining words or written } \\
\text { text; the language used by students to explain something }\end{array}$ \\
\hline
\end{tabular}

\section{RESULT AND DISCUSSION}

Mathematical representations are needed in solving assignment problems, because assignment problems use a mathematical model as a problem-solving approach. The main stages that must be passed in the process of solving the Operations Research problem are: Siang (2011)

1. Problem Definition
a. Purpose Function
b. Contrain Function
c. Decision Variable

2. Model Development

3. Model Solving

4. Validation Model

5. Implementation

The types of problems that have been solved using the techniques in Operations Research include the following figure:

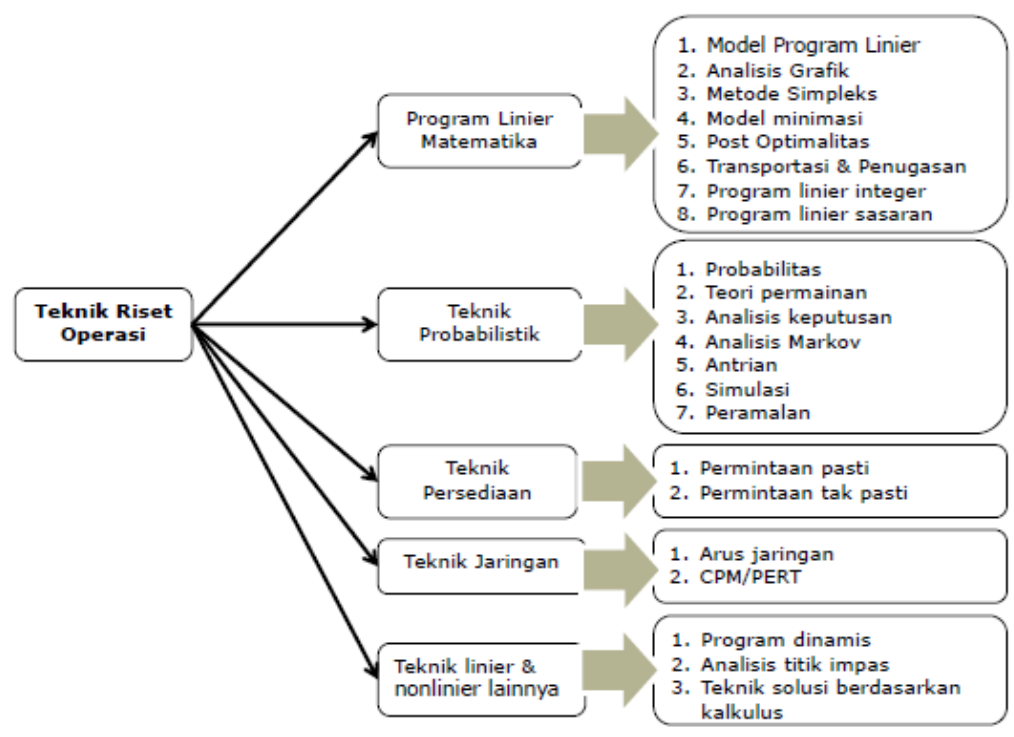

Figure 1 Types of Operations Research Problems 
Figure 1 shows that there are 5 types of problems that can be solved using techniques in Operations Research, namely linear mathematics programming, probabilistic techniques, inventory techniques, network engineering and other linear and non-linear techniques. The assignment problems discussed in this study are categorized as linear mathematics programs. To examine the mathematical representation abilities of students, this is done by giving the research subject a representation test and given time to complete it. Then the research subjects were interviewed based on the results of their work. The data was collected at least twice with different types of questions but with the same concept of solving. The results of written work and interviews used question 1 (first data) through the provision of the First Represestation Test (TR 1) compared to the results of the second written work (second data) through the provision of the Second Represestation Test (TR 2).

\begin{tabular}{|c|c|c|c|c|}
\hline \multirow{2}{*}{ Tim } & \multicolumn{4}{|c|}{ Lokasi pertandingan } \\
\hline & Raleigh & Atlanta & Durham & Clemson \\
\hline A & 210 & 90 & 180 & 160 \\
\hline B & 100 & 70 & 130 & 200 \\
\hline C & 175 & 105 & 140 & 170 \\
\hline $\mathrm{D}$ & 80 & 65 & 105 & 120 \\
\hline E & 95 & 115 & 120 & 100 \\
\hline
\end{tabular}

Figure 2 First Representation Test

Figure 2 is the first representation test question given to 3 research subjects. The following are the results of high-ability student work:

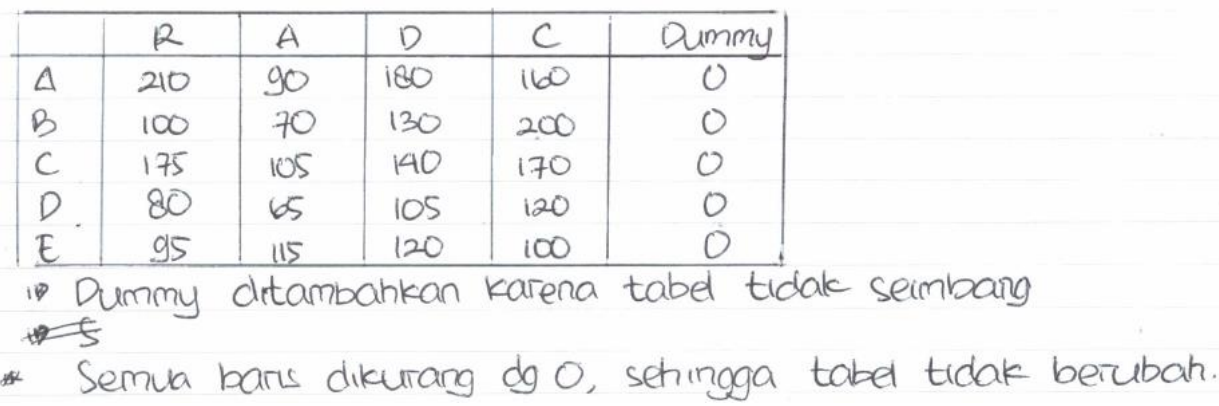




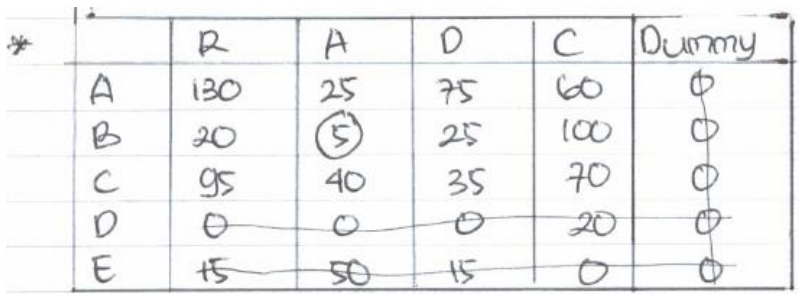

* Revisi tabel
\begin{tabular}{|c|c|c|c|c|c|}
\hline & $R$ & $A$ & $D$ & $C$ & Dummy \\
\hline$A$ & 125 & 20 & 70 & 55 & 0 \\
$B$ & 15 & 0 & 20 & 95 & 0 \\
$C$ & 90 & 35 & 30 & 65 & 0 \\
$D$ & 0 & 0 & 0 & 20 & 5 \\
\hline E & 15 & 50 & 15 & 0 & 5 \\
\hline Reuisi tabel & tab \\
\hline A & $R$ & $A$ & $D$ & $C$ & Dummy \\
\hline A & 105 & 0 & 50 & 35 & 0 \\
B & 15 & 0 & 20 & 95 & 20 \\
C & 70 & 15 & 10 & 45 & 0 \\
$D$ & 0 & 0 & 0 & 20 & 25 \\
$E$ & 15 & 50 & 15 & 0 & 25 \\
\hline
\end{tabular}

* Revisi tabel

\begin{tabular}{|l|l|l|l|l|l|}
\hline & $R$ & $A$ & $D$ & $C$ & Dummy \\
\hline$A$ & 95 & 0 & 40 & 35 & 0 \\
$B$ & 5 & 0 & 10 & 95 & 20 \\
$C$ & 60 & 15 & 0 & 45 & 0 \\
$D$ & 0 & 10 & 0 & 30 & 35 \\
$E$ & 5 & 50 & 5 & 0 & 25 \\
\hline
\end{tabular}

* Penugasan

\begin{tabular}{|l|c|c|c|c|c|}
\hline & $R$ & $A$ & $D$ & $C$ & Dummy \\
\hline$A$ & 95 & $X$ & 40 & 35 & $L O J$ \\
$B$ & 5 & $L U J$ & 10 & 95 & 20 \\
$C$ & 60 & 15 & 101 & 45 & $X$ \\
$D$ & $L 01$ & 10 & $X$ & 30 & 35 \\
$E$ & 5 & 50 & 5 & $L O J$ & 25 \\
\hline
\end{tabular}

Penugasan
$A$ ke Aummy
$B$ Ke A
$=0$
$C$ ke $P$
$=70$
$D$ ke R
$=140$
E ke C
$=80$
Total

Figure 3 Job Results High Ability Students TR1 
Figure 3 is the result of the work of subject 1, namely students with high abilities in solving the first representation test questions. From these answers, the data analysis was carried out as follows:

The resulting mathematical representation ability

a. Representation in understanding the problem

In question TR1, it is described that the subject RY uses representations in the form of figures / tables in solving problems.

b. Representation in problem solving planning stage

In this stage, it is described that initially the subject RY uses a table representation, then the subject RY uses a written text representation to clarify the problem.

c. Representation in the problem solving stage

In this stage, it is described that the subject RY uses the form of written text and images. The subject starts off by adding dummy columns to balance the matter and the next steps are described in detail. And the last thing is the assignment of each team and the location of the match and the total minimum distance has also been completed.

d. Representation in the problem-solving stage of checking back

In this stage, it is described using representations in the form of symbols and but not in the form of words to provide an explanation of confidence in the answer.

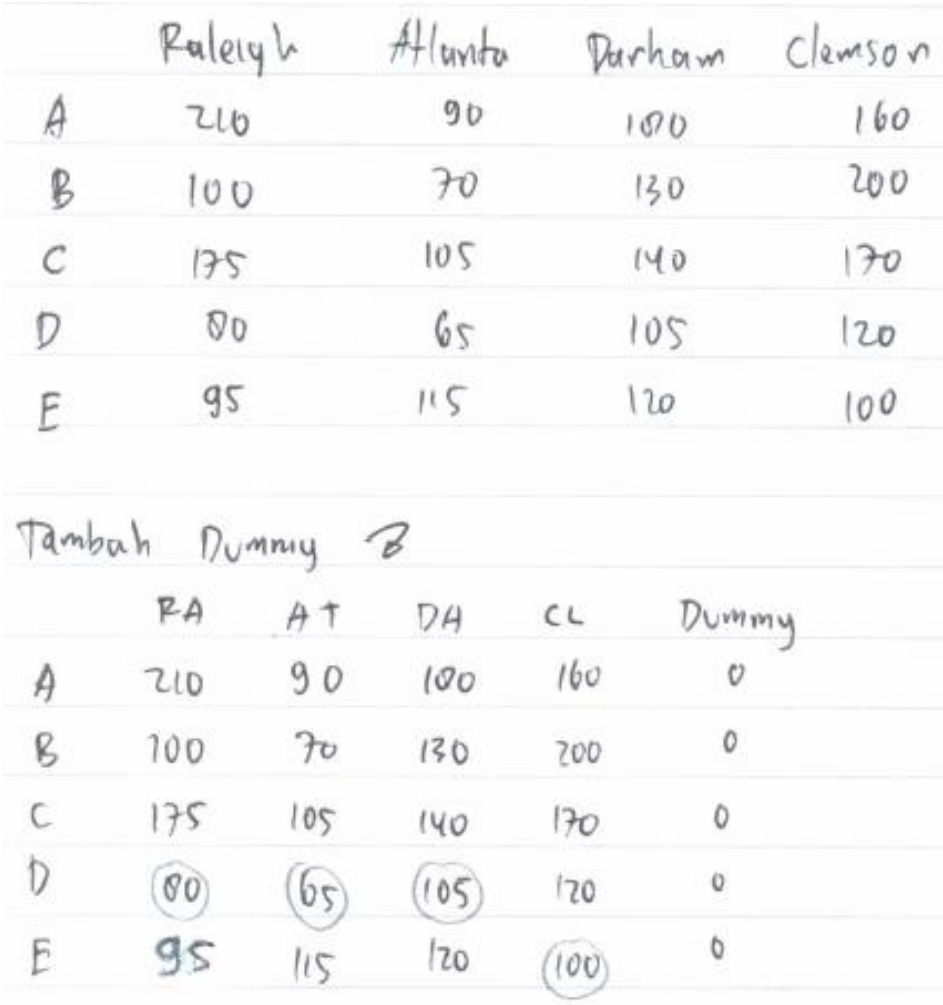



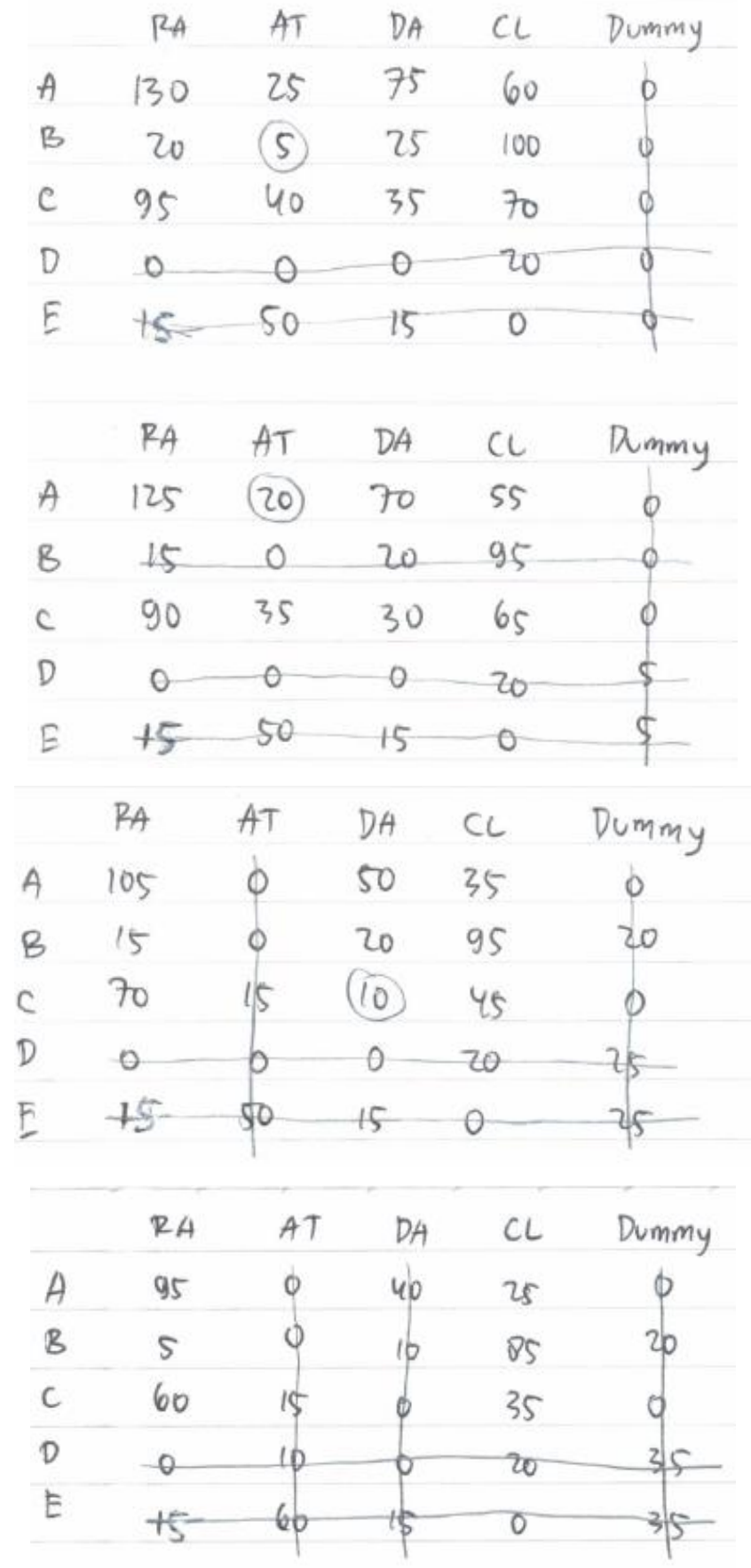

$\begin{array}{cccccc} & \text { RA } & \text { AT } & \text { DA } & C L & \text { Dummy } \\ A & 95 & 0 & 40 & 25 & {[0]^{4}} \\ B & 5 & {[0]^{5}} & 10 & 85 & 20 \\ C & 60 & 15 & {[0]^{3}} & 35 & 0 \\ D & {[0]^{2}} & 10 & 0 & 20 & 35 \\ E & 15 & 60 & 15 & {[0]^{1}} & 35\end{array}$




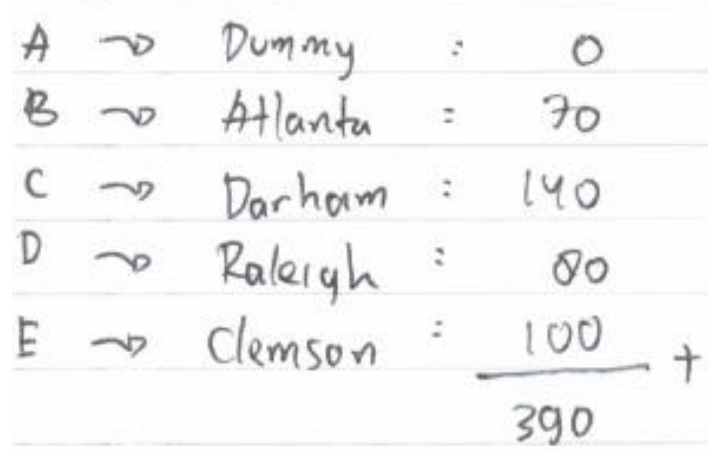

Figure 4 Job Results of Medium Ability Students TR1

Figure 4 is the result of the work of subject 2, namely students with moderate abilities in solving the first representation test questions. From these answers, the data analysis was carried out as follows:

The resulting mathematical representation ability

a. Representation in understanding the problem

Pada soal TR1, dideskripsikan bahwa subjek AG menggunakan representasi In question TR1, it is described that the subject of AG uses representations in tabular form in solving problems.

b. Representation in problem solving planning stage

In this stage, it is described that initially the AG subject uses a table representation, then the AG subject does not use a written text representation to clarify the problem.

c. Representation in the problem solving stage

In this stage, it is described that the subject of AG does not represent every step of the solution taken in the form of written text and pictures in detail / complete.

d. Representation in the problem-solving stage of checking back

In this stage, it is described using representations in symbolic form, but not in the form of words to provide an explanation of confidence in the answer.

\begin{tabular}{|c|c|c|c|c|c|}
\hline & $R$ & A & D & $c$ & Dummy \\
\hline$A$ & 210 & 90 & 180 & 160 & 0 \\
\hline B & 100 & 70 & 130 & 200 & 0 \\
\hline c & 175 & 105 & 140 & 170 & 0 \\
\hline D & 80 & 65 & 105 & 120 & 0 \\
\hline$E$ & 95 & 115 & 120 & 100 & $0 v$ \\
\hline
\end{tabular}




\begin{tabular}{|c|c|c|c|c|c|}
\hline & $R$ & $A$ & $D$ & $C$ & Dummy \\
\hline$A$ & 130 & 25 & 75 & 60 & $\phi$ \\
$B$ & 20 & 5 & 25 & 100 & $\phi$ \\
$C$ & 95 & 40 & 35 & 70 & $\phi$ \\
$D$ & 0 & 0 & 0 & 20 & 0 \\
\hline$E$ & 15 & 5 & 15 & 0 & 0 \\
\hline
\end{tabular}

* Revisi Taber

\begin{tabular}{|c|c|c|c|c|c|}
\hline & $R$ & $A$ & $D$ & $C$ & Dumy \\
\hline$A$ & 125 & 20 & 70 & 55 & $\phi$ \\
$B$ & 15 & 0 & 20 & 95 & 0 \\
$C$ & 90 & 35 & 30 & 65 & $\phi$ \\
$D$ & 0 & 0 & 0 & 20 & 5 \\
$E$ & 15 & 50 & 15 & 0 & 4 \\
\hline
\end{tabular}

* Revisi Taber

\begin{tabular}{|c|c|c|c|c|c|}
\hline & $R$ & $A$ & $D$ & $C$ & Dummy \\
\hline$A$ & 105 & 0 & 50 & 35 & $\phi$ \\
$B$ & 15 & 0 & 20 & 95 & 20 \\
$C$ & 70 & 15 & 10 & 45 & 0 \\
$D$ & 0 & 0 & 0 & 20 & 25 \\
$E$ & 15 & 50 & 15 & 0 & 45 \\
\hline
\end{tabular}

* Revisi Taber

\begin{tabular}{|c|c|c|c|c|c|}
\hline & $R$ & $A$ & $D$ & $C$ & Dunmy \\
\hline$A$ & 95 & $\phi$ & 40 & 35 & $P$ \\
$B$ & 5 & $\phi$ & 10 & 95 & 20 \\
$C$ & 60 & 15 & 0 & 45 & 0 \\
$D$ & 0 & 10 & 0 & 30 & 35 \\
$E$ & 5 & 50 & - & 0 & 25 \\
\hline
\end{tabular}

Penugasan

\begin{tabular}{|c|c|c|c|c|c|}
\hline & $R$ & $A$ & $D$ & $C$ & Dummy \\
\hline$A$ & 95 & $\not X$ & 40 & 35 & {$[0]$} \\
$B$ & 5 & {$[0]$} & 10 & 95 & 20 \\
$C$ & 60 & 15 & {$[0]$} & 45 & $\not X$ \\
$D$ & {$[0]$} & 10 & $\not 2$ & 30 & 35 \\
$E$ & 5 & 50 & 5 & {$[0]$} & 25 \\
\hline
\end{tabular}

Figure 5 Job Results of Low Ability Students TR1 
Figure 5 is the result of the work of subject 3, namely students with low abilities in solving the first representation test questions. From these answers, the data analysis was carried out as follows:

The resulting mathematical representation ability

a. Representation in understanding the problem

In TR 1, it is described that HR subjects use representations in the form of images or tables in solving problems.

b. Representation in problem solving planning stage

In this stage, it is described that initially the HR subject uses a table representation, then the HR subject uses a written text representation to clarify the problem.

c. Representation in the problem solving stage

In this stage, it is described that the HR subject represents each solving step taken in the form of written text and images, but there is no clear answer at the representation of this stage.

e. Representation in the problem-solving stage of checking back

In the stage of re-examining the problem solving solution for the representation test of question 1, the HR subject did not do it and there was no answer at this stage of representation.

Furthermore, a second representation test was carried out Biaya yang harus dikeluarkan oleh suatu perusahaan untuk mengalokasikan 4 orang pekerja pada 3
buah pekerjaan yang berbeda ditampilkan pada table. Masing-masing pekerja bisa melakukan semua
pekerjaan tersebut tetapi dengan biaya yang berbeda-beda. Carilah siapa yang harus melakukan tiap-
tiap pekerjaan tersebut untuk meminimumkan biaya keseluruhan.

\begin{tabular}{|c|c|c|c|}
\hline \multirow{2}{*}{ Pekerja } & \multicolumn{3}{|c|}{ Pekerjaan } \\
\cline { 2 - 4 } & 1 & 2 & 3 \\
\hline 1 & 7 & 3 & 5 \\
\hline 2 & 2 & 2 & 1 \\
\hline 3 & 6 & 5 & 3 \\
\hline 4 & 3 & 4 & 7 \\
\hline
\end{tabular}

Figure 6 Second Representation Test

Figure 6 is the second representation test question given to 3 research subjects. The results of the second representation test show consistency, similarity of views and opinions with the results of the first representation test, so there is no need to collect third data.

This research is in line with previous research, such as that conducted by Ulandari (2015) Finds Students who have the basic ability level of the upper group, their visual representation ability is in the high category, the symbol representation is in the medium category, the verbal representation is in the low category. Students who have the 
intermediate level of basic ability, the ability of visual representation and symbols are in the medium category and verbal representation in the very low category. Students who have a lower level of basic group skills, their visual representation ability are in the medium category, their symbol representation is low, their verbal representation is very low. Research conducted by Izati (2017) about the analysis of the increase in the ability of students' mathematical representation in terms of gender differences, showing an increase in the ability of the low category and the mathematical representation ability of male students is higher than female students and there are no male students who have high category mathematical representation abilities but there are female students who have the category high. In this study, provide results about the type of representation possessed by each research subject based on the level of mathematical abilities possessed.

\section{CONCLUSION}

Based on the results of the research, it can be concluded that the mathematical representation of high, medium and low-ability students of the Informatics Engineering Study Program, Universitas Nusantara PGRI Kediri in solving assignment problems in the Operations Research course is that high-ability students can complete multiple representations, namely using visual and symbolic representations. $\mathrm{n}$ well, but lacks in verbal representation. Likewise for the mathematical representation ability of students with moderate abilities is having multiple representations, doing well in visual and symbolic representations, but there are steps in solving that have been missed and still lacking in the implementation of the final result which lies in the verbal representation. Low-ability students only provide visual representations, while symbolic representations still have errors and and verbal representations are not done verbally. The mathematical representation ability produced by the three students is a form of mathematical ability possessed by the three of them, so that better learning tools are needed to improve students' mathematical abilities.

\section{REFERENCES}

Aminudin (2005). Prinsip-Prinsip Riset Operasi. Jakarta: Erlangga

Basir, M. A., \& Maharani, H. R (2016). Reasoning Ability Students in Mathematics Problems Solving Viewed from Cognitive Style. Prosiding In The 2nd International Seminar On Educational Technology May 2016 p. 99-102

Gagatsis, Anthanasios and Iliada Elia (2004). The Effects Of Different Modes Of Representation On Mathematical Problem Solving. Proceeding of the 28th Conference of the International Group for the Psychology of Mathematics Education. Vol 22 pp 447-454.

Goldin, G.A., Kaput, J.J (2015). A Joint Perspective on The Idea of Representation in Learning and Doing Mathematics. ResearchGate. Diakses oktober 2019 dari https://www.researchgate.net/publication/269407907

Hayatunnizar (2017). Meningkatkan Kemampuan Representasi Matematis Melalui Penerapan Model Problem Base Learning. Jurnal Didaktik Matematika. 4 (1), 119128.

Irawati Sri, dan Sri Indriati Hasanah (2016). Representasi Mahasiswa Berkemampan Matematika Tinggi Dalam Memecahkan Masalah Program Linier. Jurnal Inovasi Volume 18, Nomor 1 Januari 2016. 
Izati, Dwi dkk (2017). Analisis Peningkatan Representasi Matematis Siswa SMA Ditinjau dari Perbedaan Gender. Jurnal Didaktik Matematika Vol. 4 No. 2 September 2017.

Junita, Ranisa (2016). Kemampuan Representasi dan Komunikasi Matematis Peserta Didik SMA Ditinjau dari Prestasi Belajar dan Gaya Kognitif. Pythagoras: Jurnal Pendidikan Matematika Volume 11 - Nomor 2, Desember 2016, (193-206).

Kartini (2009). Peranan Representasi Dalam Pembelajaran Matematika. Prosiding Seminar Matematika dan Pendidikan Matematika FMIPA UNY 05 Desember 2009.

Krawec, Jenifer Lee (2010). Problem Representation and Mathematical Problem Solving of Students of Variying Math Ability. Electrovnic Theses and Disertation. http://scholarlyrepository.miami.edu/cgi/viewcontent.cgi?article $=1454 \&$ context= oa dissertations

NCTM (2000). Principles and Standards for School Mathematics. Reston VA: NCTM.

Sabirin, Muhamad (2014). Representasi Dalam Pembelajaran Matematika. JPM IAIN Antasari,Vol. 01 No. 2, 33-34.

Sanjaya, Indrayana Ika, dkk (2018). Kemampuan Representasi Siswa Pada Materi Lingkaran Berdasar Gaya Belajar Honey Mumford. Kontinu: Jurnal Penelitian Didaktik Matematika Vol 2 No. 2, Oktober 2018.

Shofia, Niska (2019). Analisis Representasi Matematis Mahasiswa Teknik Informatika Dalam Menyelesaikan Soal Riset Operasi, Jurnal Efektor, Volume 6 Issue 2, 136141

Siang, Jong Jek (2011). Riset Operasi Dalam Pendekatan Algoritmis. Yogyakarta: Andi

Sugiyono (2007). Metode Penelitian Pendidikan: Pendekatan Kuantitatif, Kualitatif dan R\&D. Bandung: Alfabeta.

Ulandari, A. R. P., Hudiono, B., \& Bistari (2015). Kemampuan representasi matematis menyelesaikan soal open-ended menurut tingkat kemampuan dasar materi segiempat di smp. Jurnal Pendidikan dan Pembelajaran Khatulistiwa, Vol 4, No 6, h. $1-10$.

Wu-Yin Hwang, et all (2007). Multiple Representation Skills and Creativity Effects on Mathematical Problem Solving Using A Multimedia Whiteboard System. Educational Technology \& Society. 10 (2), 191-212 